\title{
8. CLAY MINERAL STRATIGRAPHY OF THE RIO GRANDE RISE AND SOUTHERN BRAZIL BASIN, WESTERN SOUTH ATLANTIC OCEAN ${ }^{1}$
}

\author{
Herman B. Zimmerman, Department of Civil Engineering, Union College, Schenectady, New York
}

\begin{abstract}
Clay mineral facies of DSDP Sites (Legs 39 and 72) in the western South Atlantic Ocean reflect the region's tectonic and paleoceanographic events. An abrupt change to a smectite-dominated assemblage occurs in the lower Tertiary and represents the onset of extensive volcanic activity at that time. In the Coniacian-Campanian section of Site 516, a wellcrystallized kaolinite suggests the presence of a deeply weathered continental remnant at the crest of the Rio Grande Rise and strongly opposed current systems at shallow and mid-water depths on the northern flanks of the Rise. Within the Rio Grande Gap, initiation of Antarctic Bottom Water flow occurs within the time span represented by an early Eocene-Oligocene unconformity in the sediment section of Site 515 at the northern terminus of the Vema Channel.
\end{abstract}

\section{INTRODUCTION}

Core materials from the Deep Sea Drilling Project (DSDP) provide an excellent stratigraphic framework with an adequate resolution to allow studies of the evolution of clay mineral assemblages. This study focuses primarily on the barrier-threshold combination of the Rio Grande Rise and Vema Channel, a key control point for tectonic, paleoclimatic, and paleoceanographic effects throughout the entire western South Atlantic Ocean.

The history of oceanic circulation in this area is closely tied to the tectonic evolution of the Rio Grande Rise, one of the world's major aseismic ridges. The Rio Grande Rise has over $4000 \mathrm{~m}$ of relief (Fig. 1) and therefore acts as a barrier to longitudinal flow of all intermediate and deep water masses of the southwestern Atlantic (e.g., Reid et al., 1977). The Rio Grande Gap forms the westernmost deep passage connecting the Brazil and Argentine basins. To the east another large depression, the Hunter Channel, also connects the Brazil and Argentine basins (Burckle and Biscaye, 1971). Incised into the Rio Grande Gap is the Vema Channel (LePichon et al., 1971), a narrow bifurcated passageway with a sill depth at approximately $4600 \mathrm{~m}$ (Lonardi and Ewing, 1971). The abyssal circulation to the south of the Rio Grande Rise is dominated by Antarctic Bottom Water (AABW), which forms a cyclonic gyre within the Argentine Basin. At the northern margin of the Argentine Basin, however, the flow is partially deflected northward through the Vema Channel and into the Brazil Basin. Current velocities on the order of $15-25 \mathrm{~cm} / \mathrm{s}$ have been measured within the restricted channel (Reid et al., 1977; Johnson et al., 1976). Northward flow of AABW has been documented also by the presence of displaced Antarctic diatoms along the western boundary of the Brazil Basin and as far north as $30^{\circ} \mathrm{N}$ (Burckle, 1976; Burckle et al., 1975).

\footnotetext{
${ }^{1}$ Barker, P. F., Carlson, R. L., Johnson, D. A., et al., Init Repts. DSDP, 72: Washing. ton (U.S. Govt. Printing Office).
}

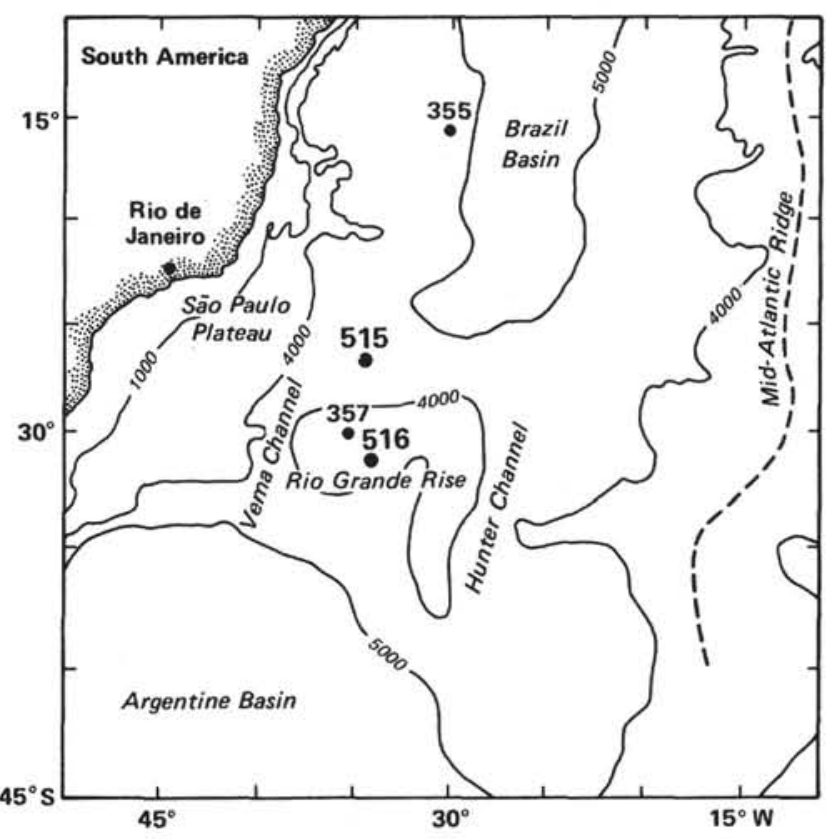

Figure 1. Regional setting of the western South Atlantic, showing locations of drill sites (depths in meters).

Previous investigators have shown that the fine-fraction component of nonbiogenic sediment, predominantly the clay minerals, may be usefully employed for paleoceanographic interpretation. Distribution of clay minerals in surface sediments reflects the global climatic regime, sedimentary provenance, and the various modes of transport within a basin (Biscaye, 1965; Griffin et al., 1968; Rateev et al., 1969). In the Rio Grande Rise area, clay mineral distribution shows that the Rise forms an important clay mineral facies boundary in the southwestern Atlantic. Using these criteria, Biscaye (1965) suggests that fine-grained sediment is transported northward through the Vema Channel by AABW flow. This has been substantiated by Lawrence (1979) on the basis of oxygen isotope values of the silicate sediment fraction. 
Other clay mineral studies of deep ocean stratigraphy in the Atlantic include: Zimmerman (1977), an examination of the sediments from Leg 39; Chamley and Robert (1979), a study of the Late Cretaceous and early Paleogene stratigraphy of the Atlantic; and Robert (1980), an examination of Cenozoic sediments and their relation to climate and currents. Using piston cores, Melguen and others (1978) demonstrated the probable connection between dissolution cycles for biogenic carbonate and fluctuations in the flow of AABW since the early Miocene. They also attempted to label AABW and North Atlantic Deep Water (NADW) with diagnostic clay mineral assemblages.

The study presented here is based upon the materials collected on DSDP Legs 39 and 72. Sites 355 (4901 m water depth) and $515(4252 \mathrm{~m})$ are located in the Brazil Basin (Fig. 1) and document the sediment deposition in the deep oceanic areas to the north of the Rio Grande Rise. Sites $357(2086 \mathrm{~m})$ and $516(1313 \mathrm{~m})$ are shallower and are located close to one another near the crest of the Rio Grande Rise. In this study we will compare the clay mineral suites of the two sets of stratigraphic columns and interpret their relationships to paleoceanographic factors.

\section{METHODS}

Samples were taken from the four sites so that good representation was obtained of all sediment facies and characteristic horizons. In all, 137 samples, at an average downcore interval of $25 \mathrm{~m}$, were analyzed by standard X-ray diffraction (XRD) procedures.

Detailed descriptions of sample preparation for XRD analysis are given in Biscaye (1965) and Jackson (1969). Calcium carbonate was removed by overnight treatment with $0.6 \mathrm{~N}$ acetic acid solution, followed by successive decantation until floculation ceased (usually three repetitions), then settling in accordance with calculated times to allow separation of the $2-37 \mu \mathrm{m}$ (silt) and $<2 \mu \mathrm{m}$ (clay) fractions. The two separate suspensions were then concentrated by decantation to remove excess water, and the sediment pastes were smeared on glass slides (Gibbs, 1965). Each slide was analyzed by XRD both before and after ethylene glycol solvation $\left(1 \mathrm{hr}\right.$. at $\left.60^{\circ} \mathrm{C}\right)$. The clay slides were run through a scan of $3-14^{\circ} 2 \theta$ with a slow scan speed in the $24-26^{\circ} 2 \theta$ range; the silt slides were run through a range of $3-35^{\circ} 2 \theta$ at a scan speed of $2^{\circ} 2 \theta /$ minute. Analysis was performed with a General Electric XRD-7 diffractometer with nickel-filtered $\mathrm{CuK} \alpha$ radiation.

Major mineral phases on the clay slide were identified by their basal reflections. The area under the $7.1 \AA$ peak was used as an indicator of the abundance of chlorite and kaolinite, and the slow-scan method of Biscaye (1964) was used to identify and separate these two minerals. Illite (or mica) was recognized by a well-defined peak at $10 \AA$ that was unaffected by ethylene glycol solvation. Irregular mixedlayer (illite-smectite) clay was estimated by the area above background between the $10 \AA$ peak of illite and the $14 \AA$ chlorite peak. A broad $17 \AA$ peak after solvation was routinely assigned to smectite (montmorillonite). Reynolds and Hower (1970) have demonstrated that a 17 Å peak may represent pure montmorillonite or a mixed-layer micamontmorillonite, whereas decreasing peak intensity, resulting in a broad peak, represents an increasing abundance of mica layers (see also Hayes, 1973, and Eslinger and Savin, 1976). For this investigation, the area under the $17 \AA$ peak is employed as a measure of the relative abundance of "smectite."

Semiquantitative estimates of the relative amounts of crystalline clay components were determined by concentration factors described by Biscaye (1965), whereby proportions of smectite, mixed-layer (illite-smectite), kaolinite, illite, and chlorite were normalized to $100 \%$. Only minor amounts of palygorskite were identified.

In complex sediment mixtures, areas of X-ray diffraction peaks indicate mineral abundance, orientation, absorption, crystal perfection, and variations in composition. Inspection of the diffractograms for this study revealed the potential of the total clay reflectivity as a po- tent measure of clay variation. We have chosen the term "total clay index" (TCI) for this because of the covariance and contribution of all the clay mineral peak areas to this measure (previously termed "crystallinity index" in Zimmerman, 1982b).

The most convenient way to quantify this measure was to sum the areas (in $\mathrm{mm}^{2}$ ) above background of the $17,10,11-13$, and $7.1 \AA$ peaks (solvated, under constant machine conditions) after multiplying by the factors of Biscaye (1965). Two diffractogram traces, therefore, may indicate approximately the same relative abundance of individual clay mineral species, but the TCI may differ widely, primarily reflecting, we suspect, clay abundance and crystal perfection of all the clay minerals. In the North Atlantic (Zimmerman, 1982a), the TCI defines mineral provinces that are dependent on source, current transportation, basin physiography, and primarily the rate of fine-fraction deposition.

Another measure that is effective in describing sedimentary phenomena associated with deep-ocean deposition is the ratio: TCI/ quartz (calculated from dimensionless values of TCI and quartz intensity). The intensity of the quartz peak ( $4.26 \AA$ ) describes the silt-sized (2-37 $\mu \mathrm{m})$ continental contribution, whereas the TCI represents the fine-fraction clay deposition. The ratio then serves as a measure of the relative contribution of fine-grained and silt-sized sediments.

For the silt-sized $(2-37 \mu \mathrm{m})$ component, we have calculated mineral ratios based on peak intensities of quartz $(4.26 \AA)$, plagioclase feldspar $(3.18 \AA)$, and orthoclase feldspar $(3.25 \AA)$. The presence of clinoptilolite, phillipsite, and cristobalite are also noted.

\section{RESULTS AND DISCUSSION}

\section{Brazil Basin}

Site 515 is located in the southern Brazil Basin approximately $200 \mathrm{~km}$ north of the exit of the Vema Channel. The main objective of drilling at this location was to determine the initiation and subsequent history of AABW flow through the channel. Onboard sedimentologic work (see site chapter, Site 515, this volume) established three lithologic units in the sediment sequence (Fig. 2). Units 1 and 2 consist predominantly of graybrown to greenish gray terrigenous muds and mudstones; Unit 2 sediments are distinguished on the basis of a greater biosiliceous content. Situated below a major lower Eocene-Oligocene unconformity, Unit 3 is a zeolitic to calcareous mudstone that exhibits considerable color variation as well as parallel bedding, cross lamination, and extensive bioturbation. Unit 3, therefore, indicates redeposition and exposure to the winnowing effects of current activity at the seafloor.

The clay mineral assemblage at Site 515 (Fig. 2) is dominated by smectite with the abundance of kaolinite and chlorite increasing upwards in the sedimentary section. Although there is only small variability in clay mineral abundance, there are subtle changes that allow separation into facies that are approximately coincident with the lithologic units. Unit $2 \mathrm{~A}$ is distinguished on the basis of its greater mixed-layer (illite-smectite) content, and the lithologic variability of Unit 3 is reflected in the variability of the clay mineral suite. Unit 3 may also be distinguished by its abundance of clinoptilolite.

The TCI provides a clear stratigraphic signal to distinguish Units 1 and 2. An increase in TCI suggests an increase in the rate of deposition of fine-grained sediment of Pliocene and Quaternary age and is accompanied by an increase in the content of chlorite, kaolinite, and illite (clays that are indicative of continental sediment sources). The TCI/quartz ratio has also increased over this interval, suggesting that fine-grained material 


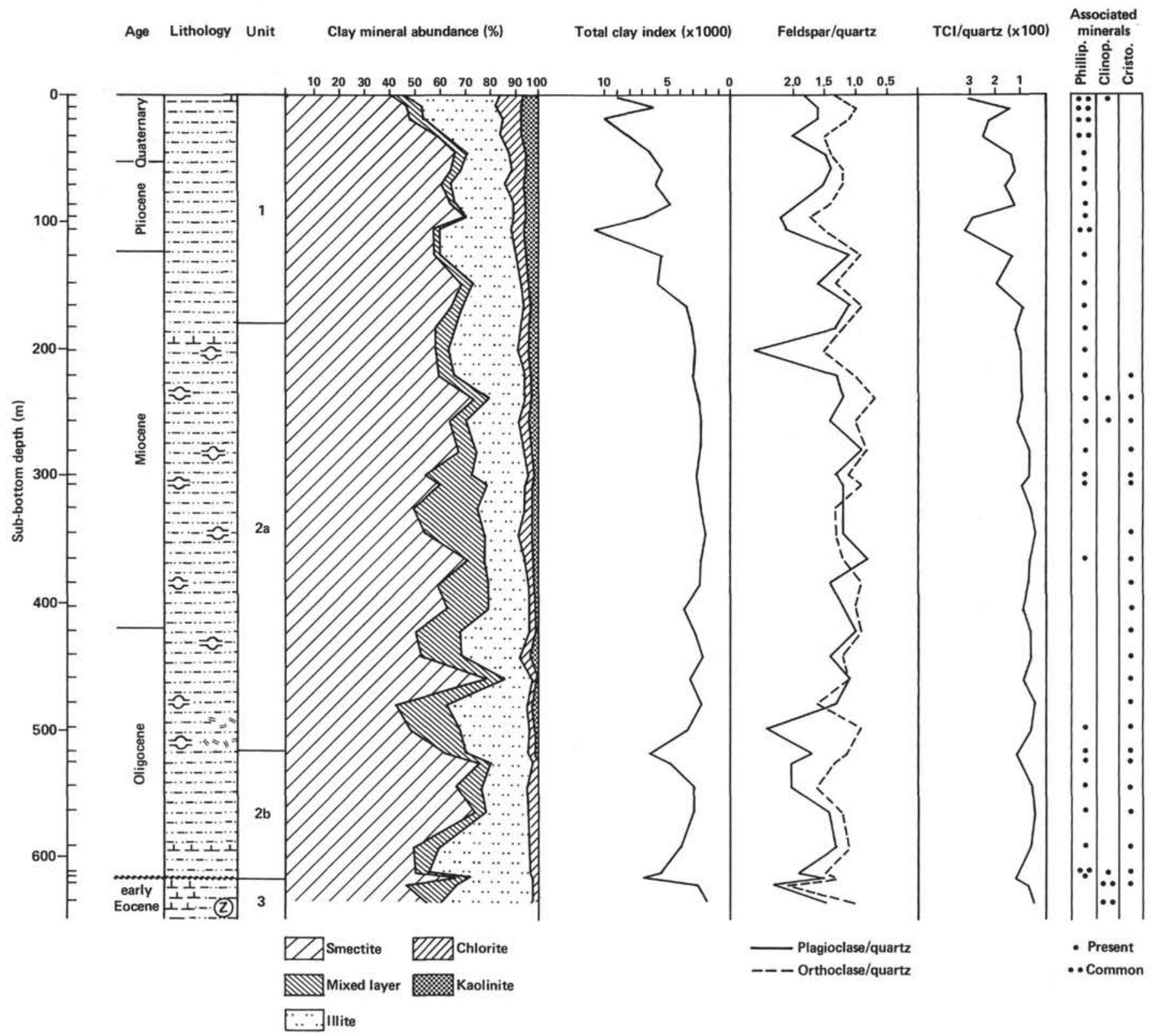

Figure 2. Summary of lithostratigraphic and mineralogic data for Site 515, Leg 72, DSDP. Phillip. = phillipsite; clinop. = clinoptilolite; Cristo. = cristobalite.

is the primary sediment input. During a time of increasingly active advance and retreat of continental ice sheets and the concomitant rapid fluctuation in sea level, the increased deposition of fine sediment may reflect a generally high level of suspended sediment in the water column.

Notable at the base of Subunit 2b is the high TCI in conjunction with a low $\mathrm{TCI} /$ quartz ratio. This reflects a relatively intense influx of both silt and clay immediately above the lower Eocene-Oligocene unconformity and reinforces the hypothesis of a current-erosional origin for this hiatus. Together with the lag deposit at the base of Unit 2 and the variability, cross lamina, and winnowing of Unit 3, a clear picture of current activity emerges. Presumably, the initiation of AABW flow into the Bra- zil Basin occurred within the time span of the hiatus. Previously deposited sediments were most probably removed by the erosional event. Oligocene deposition of Subunit $2 b$ is sporadic and probably occurred within the framework of a generally lessening current intensity. The upper boundary of Subunit 2b, however, shows a similar set of sediment parameters, suggesting deposition under a similar current regime.

Site 355 (Leg 39) is located in the center of the Brazil Basin some $700 \mathrm{~km}$ to the north of Site 515 . Two lithologic units were distinguished (Supko, Perch-Nielsen, et al., 1977). Unit 1 (Fig. 3) consists of zeolitic muds and mudstones, gray-brown to green-gray in color. Distal bioclastic turbidite sequences and thin lamina of siltsized terrestrial components occur within this unit. Un- 

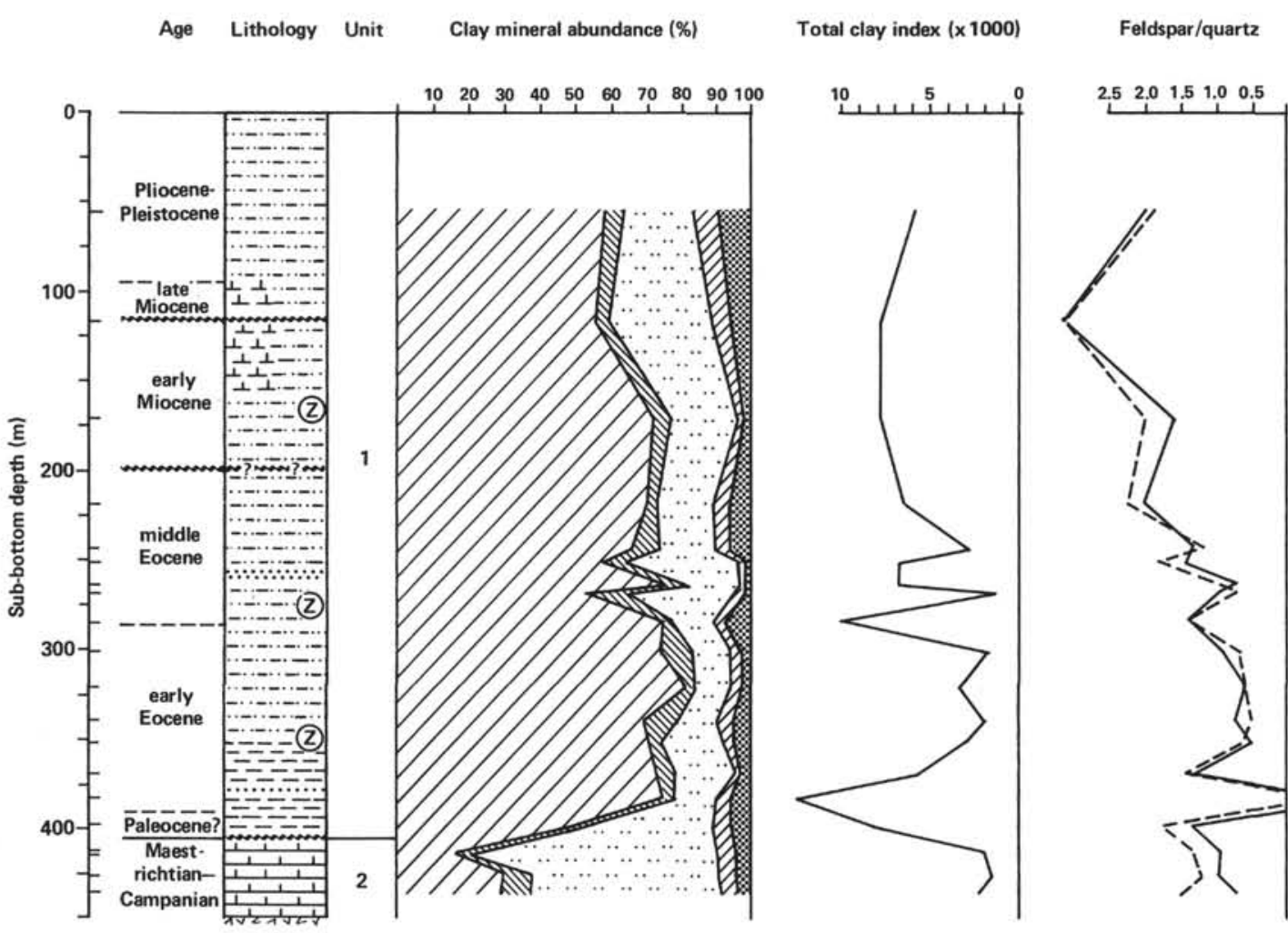

TCI/quartz $(x 100)$

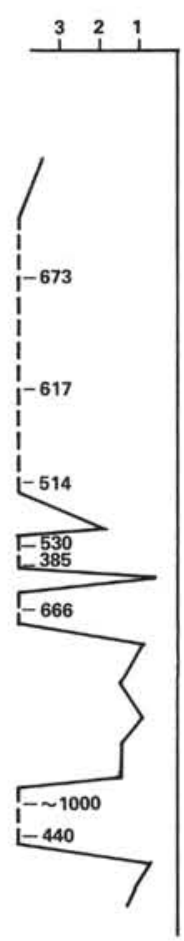

Figure 3. Summary of lithostratigraphic and mineralogic data for Site 355, Leg 39, DSDP. (See Fig. 2 for symbols.)

derlying a Maestrichtian-Paleocene(?) unconformity, Unit 2 is a marly limestone in contact with tholeiitic basalt below.

Besides constituting a lithologic unit boundary, the Maestrichtian-Paleocene(?) unconformity in the Brazil Basin also marks a major change in clay mineral assemblage (Zimmerman, 1977; Chamley and Robert, 1979). Below the unconformity, the clay mineral suite consists predominantly of illitic clays. At the unconformity, an abrupt increase of smectite occurs in the lower Tertiary sediments and smectite continues to dominate the clays throughout the section. Two other unconformities interrupt the sediment sequence within Unit 1, but the lithology and clay mineral suites are unaffected by these hiatuses.

TCI of Site 355 is highly variable in the lower and middle Eocene sediments and is probably related to episodic smectite influx from volcanic activity on the Rio Grande Rise (Zimmerman, 1977). This part of the section does not occur at Site 515. Although the correlative portions of the sediment sequences at Sites 355 and 515 are similar in relative clay abundance, the other clay and silt parameters are distinctly different. The Miocene and Pliocene sediments show a much greater TCI and TCI/ quartz ratio at Site 355 . These differences appear to be related to the different topographic settings of the sites, with Site 355 in the central basin receiving a higher proportion of clay to silt. At the terminus of the Vema Channel, the clays of Site 515 are apparently winnowed by the bottom flow, thus leaving a more silty deposit.

\section{Rio Grande Rise}

Sites 516 (1313 m water depth) and 357 (2086 m) are located on the northern flank of the Rio Grande Rise (Fig. 1). The sedimentary sections of the two sites are similar (Figs. 4 and 5) and consist of upper Eocene to Recent pelagic chalk and oozes overlying a middle Eocene section of volcanogenic material, which in turn overlies an Upper Cretaceous section consisting of silty and clayey limestones. These sites complement the basin sites by providing a record of the sediments deposited in the upper levels of the water column. Their topographically isolated position eliminates the influences of transport mechanisms operating on the deep ocean floor.

Although the sedimentary sections are similar, the detailed clay mineral stratigraphies of the two sites are quite different. The middle Eocene section is dominated by volcanogenic material, and the clay minerals of both sites consist predominantly of smectite with a small amount of mixed-layer minerals. These sediments also have a high TCI, sporadic input of large amounts of feldspar silt, and a high TCI/quartz ratio (indicating little quartz content). The association with middle Eocene volcanic material and the absence of a creditable continental source suggest that this clay facies is of a volcanogenic origin.

The volcanogenic and intermixed biogenic material of both sites indicate emplacement from an upslope position (Supko, Perch-Nielsen, et al., 1977; site chapter, Site 516, this volume). Formation of the clay mineral as- 

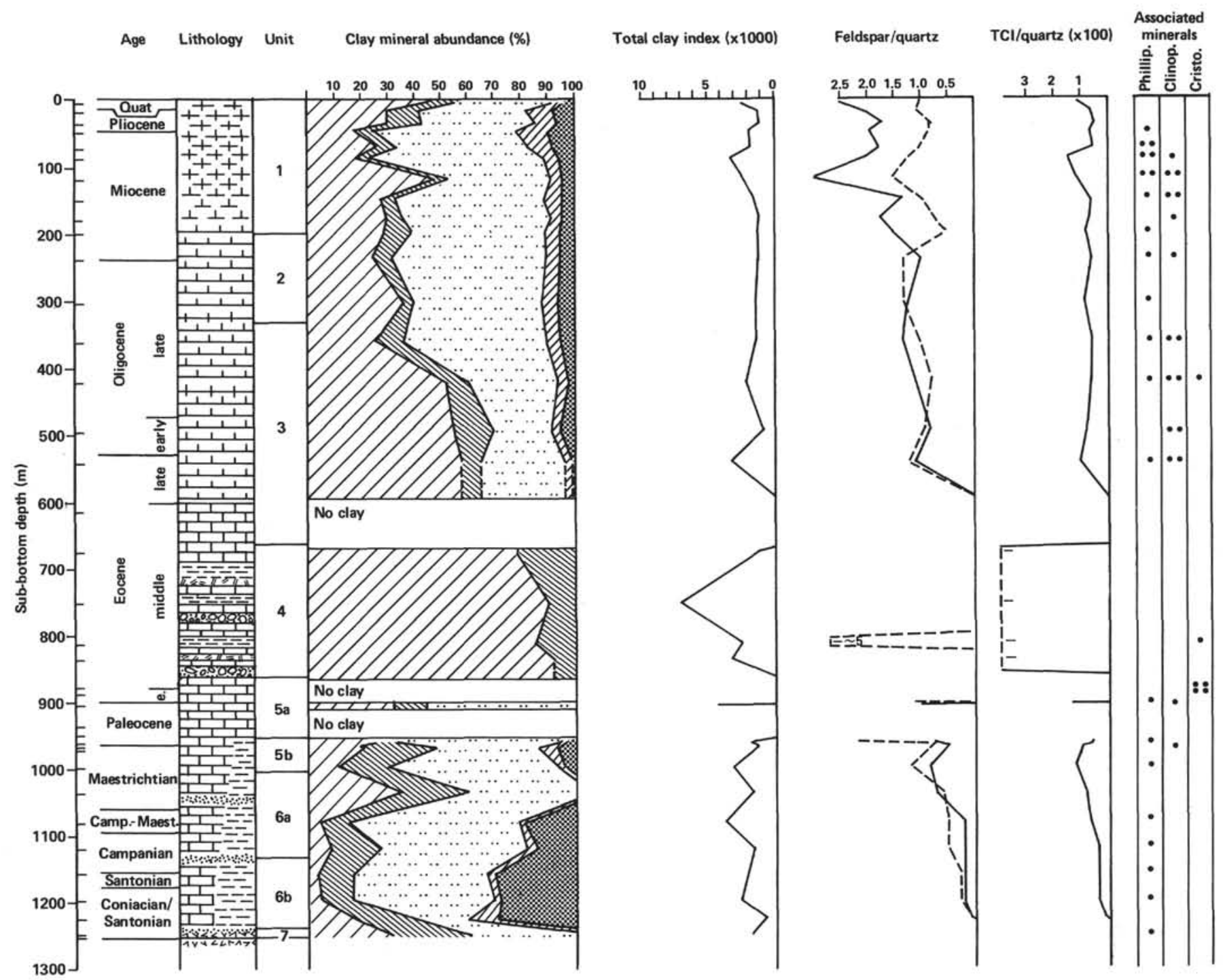

Figure 4. Summary of lithostratigraphic and mineralogic data for Site 516, Leg 72, DSDP. (See Fig. 2 for symbols.)

semblage, therefore, may have occurred in a subaerial (volcanic island) or shallow submarine environment associated with the basaltic terrane of the Rio Grande Rise. At least in part, it may also be explained as an in situ alteration of basaltic debris. Sediments directly beneath the middle Eocene volcanic event also have large concentrations of cristobalite (Figs. 4 and 5), which may represent an increase in biosiliceous productivity resulting from the availability of silica through the process of ash alteration. Cristobalite also dominates the basal sediments at Site 357.

The high smectite content from lower Eocene to Recent in the basin sites $(355,515)$ is a reflection of the initiation of volcanic activity in the early Eocene and the continuing importance of the volcanic contribution over widespread areas of the South Atlantic. Although it is difficult to estimate the date with certainty, the change to a volcanogenic assemblage appears to have occurred in the Paleocene to early Eocene (Zimmerman, 1977; Chamley and Robert, 1979). An earlier episode of smectite deposition occurs at the Santonian/Campanian boundary of Site 357 . Because of its absence at the shallower site (516), however, we suspect that this pulse of smectite may represent the erosion of a locally exposed portion of the Cretaceous basement.

Underlying the middle Eocene volcanic sediments, the marly limestones of both sites reveal a section of clay dominantly continental in nature. The Upper Cretaceous facies (illite, smectite, and mixed layer) of the Rio Grande Rise, and Site 355 as well, is similar to that reported by DaRocha et al. (1975) in recent sediments on the continental shelf adjacent to the São Paulo Plateau. The occurrence of kaolinite, however, is puzzling. Kaolinite is present in Maestrichtian sediments of a number of sites $(105,354,357,390,516)$ in the western basins of both the North and South Atlantic (Zimmerman, 1977; Chamley and Robert, 1979). Site 516, however, contains an unusual amount of well-crystallized kaolinite in the Coniacian-Campanian section. This is not repeated at any other site in the Atlantic (there is a strong kaolinite signal in the Aptian sections of both the Cape and Angola basins, Sites 361 and 364, respective- 
Age

Lithology Unit

$\begin{array}{lllllllllll}0 & 10 & 20 & 30 & 40 & 50 & 60 & 70 & 80 & 90 & 100\end{array}$

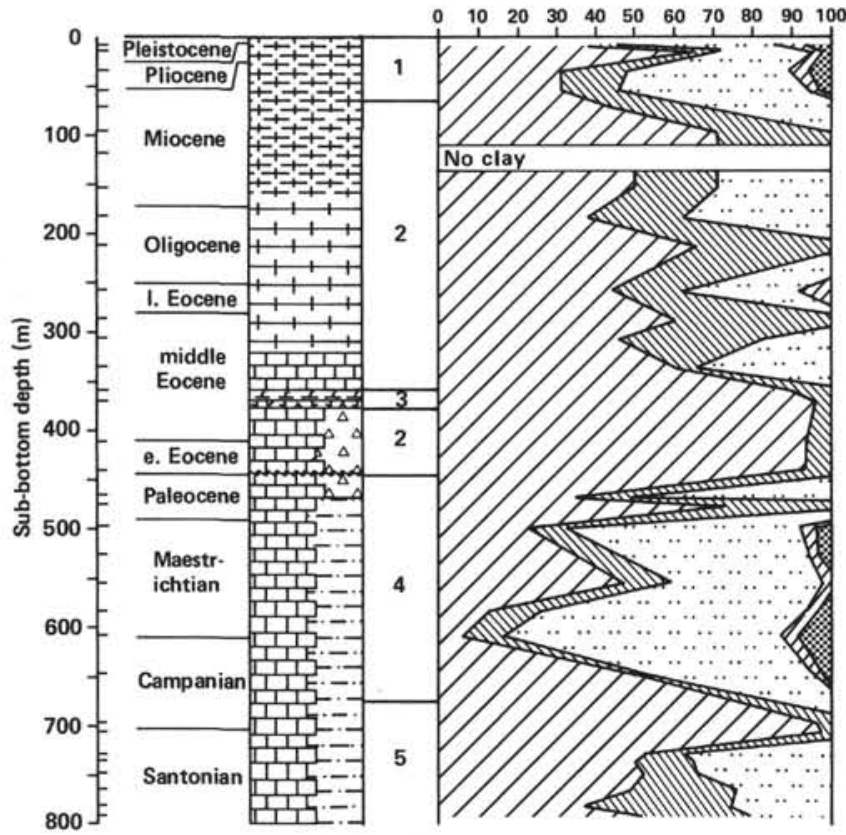

Total clay index $(x 1000)$
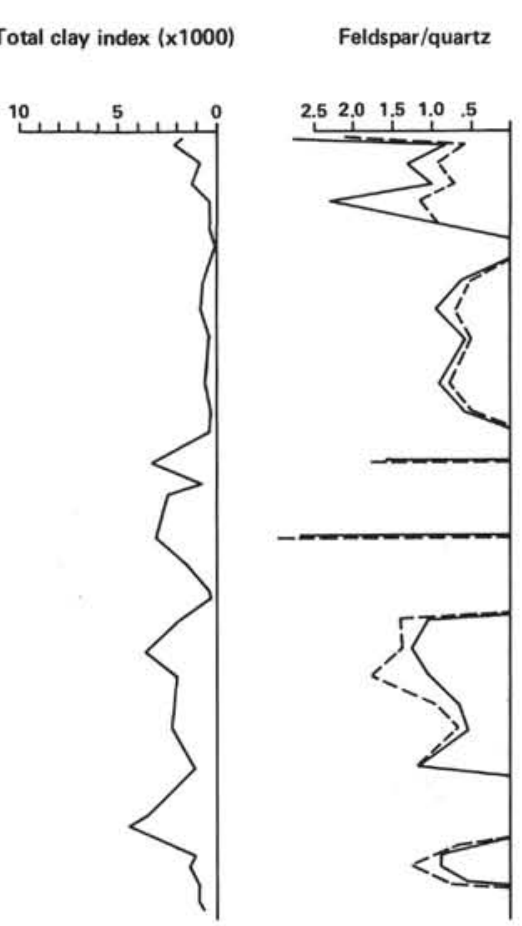

TCl/quartz $(x 100) \begin{gathered}\text { Associated } \\ \text { minerals }\end{gathered}$

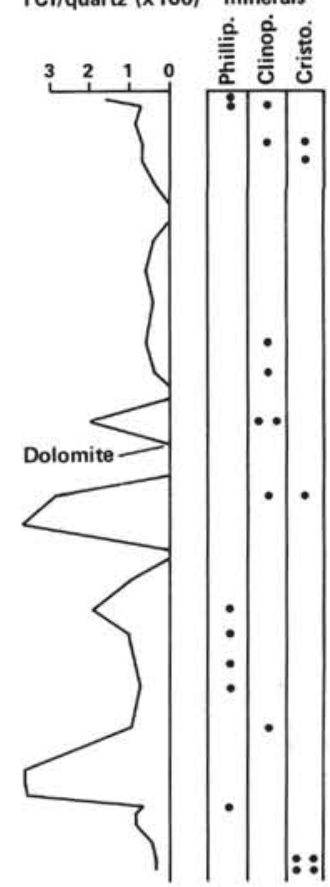

Figure 5. Summary of lithostratigraphic and mineralogic data for Site 357, Leg 39, DSDP. (See Fig. 2 for symbols.)

ly: Robert et al., 1979). Besides the great abundance of kaolinite at Site 516, the nature of the XRD trace is quite unusual. Kaolinite from most sites is normally represented by relatively broad XRD peaks; the kaolinite of the Coniacian-Campanian section, however, is represented by sharp peaks, indicative of a well-crystallized clay mineral. Considering also the presence of only a small amount of feldspar silt, we conclude that a deeply weathered source terrane had been tapped to provide this material. Therefore, a potassic-alkalic basement remnant may possibly have been exposed on the crest of the Rio Grande Rise.

It is quite surprising to find such prominent kaolinite at Site 516 , because it is completely absent at nearby Site 357. The two sites, however, show $750 \mathrm{~m}$ of vertical separation. The gradient between water mass properties, perhaps a strong halocline, must have been intense to produce so different a clay mineral facies. For the Turonian-mid-Campanian, McCoy and Zimmerman (fig. $5,1977)$ indicate that the deeper slopes of the northern flank of the Rio Grande Rise were swept by a westwardflowing current that was directed towards the Rio Grande Gap. The shallower regions underlie a southward-flowing surface current. The opposed current systems, therefore, may account for the different provenances represented by the clay mineral facies at the two sites.

The Tertiary section above the middle Eocene volcanics is characterized primarily by pelagic calcareous sediments. The clay mineral contribution is minor (note the very low TCI) and occasionally absent. At Site 516, the assemblage consists of an illitic clay with an increasing abundance of kaolinite and chlorite. Smectite is variable but averages about $40 \%$ of the clay content. Site 357 contains a clay suite much enriched in smectite, with episodic mixed-layer clay. Interspersed is an illitic clay that is similar to the assemblage at Site 516. It is difficult to reconcile the assemblages at the two sites. The shallower site (516) may be receiving a contribution of illite from an upper level water mass that may be deposited only irregularly at the deeper site. An indication that the illitic clays are an additional input at the shallower site is given by the TCI, which records a higher rate of clay sediment deposition at that position.

\section{SUMMARY}

Results of this study illustrate the effects of tectonic and paleoceanographic events upon the clay mineral stratigraphy of the western South Atlantic. Upper Cretaceous sediments of the Rio Grande Rise consist of marly limestones with a clay mineral assemblage dominated by illite, smectite, and mixed-layer minerals probably of continental origin. Well-crystallized kaolinite in the Coniacian-Campanian section of Site 516 suggests the presence of a deeply weathered continental remnant at the crest of the Rio Grande Rise. A profound change in the clay mineral assemblage signals the onset of Eocene volcanism. The clay mineral facies consists predominantly of smectite in association with volcanogenic sediments. Overlying this, the calcareous pelagic sediments of the Rio Grande Rise become more illitic in composition, whereas the muds of the Brazil Basin retain their strong smectite character. The shallower sites, therefore, may be reflecting the clay content and pelagic transport of a shallow water mass, whereas the clays of the deeper basin sites signal bottom transport processes from continental or marine basaltic terranes.

The initiation of AABW flow in Vema Channel occurred within the time span represented by the early Eo- 
cene-Oligocene unconformity at Site 515 . Better resolution is not possible because of the current-induced erosion associated with the early stages of the flow.

\section{ACKNOWLEDGMENTS}

The author wishes to thank the Deep Sea Drilling Project and the shipboard scientists of Leg 72 for the opportunity to contribute to this volume of the Initial Reports. I am grateful to Drs. Floyd McCoy (Lamont-Doherty Geological Observatory), A. Morton (Institute of Geological Science, United Kingdom), and C. Robert (Université de Marseille-Luminy), who read the manuscript and offered constructive comments. Thanks are also due to Andrew Zimmerman and Daniel Rosenfield for their assistance in the XRD laboratory. I wish to thank Union College for making available the facilities of the Cooledge X-ray Laboratory and for a Faculty Research Grant in time of need. This research was supported in part by the National Science Foundation, Grant OCE 80-08236.

\section{REFERENCES}

Biscaye, P. E., 1964. Distinction between kaolinite and chlorite in recent sediments by X-ray diffraction. Am. Mineral., 49:1281-1289. , 1965. Mineralogy and sedimentation of recent deep-sea clay in the Atlantic Ocean and adjacent seas and oceans. Geol.. Soc. Am. Bull., 76:803-831.

Burckle, L. H., 1976. Pleistocene changes in Antarctic bottom water flow through the Vema Channel. EOS Trans. Am. Geophys. Union, 57:257.

Burckle, L. H., and Biscaye, P. E., 1971. Sediment transport by Antarctic Bottom Water through the eastern Rio Grande Rise. Geol. Soc. Am. Abstracts with Programs, 3:518-519.

Burckle, L. H., Poferl-Cooke, K., and Maloney, J., 1975. Southward flowing Antarctic Bottom Water off Cape Hatteras-evidence from displaced diatoms. Geol. Soc. Am. Abstracts with Programs, $7: 34$.

Chamley, H., and Robert C., 1979. Late Cretaceous to early Paleogene environmental evolution expressed by the Atlantic clay sedimentation. Cretaceous-Tertiary Boundary Events Symposium, Proc. II, pp. 71-77.

DaRocha, J., Milliman, J. D., Santana, C. I., and Vicalvi, M. A., 1975. Upper continental margin sedimentation of Brazil, Part V-Southern Brazil. Contrib. Sedimentol., 4:117-150.

Eslinger, E. V., and Savin, S. M., 1976. Mineralogy and $\mathrm{O}^{18} / \mathrm{O}^{16} \mathrm{ra}-$ tios of fine-grained quartz and clay from Site 323. In Hollister, C. D., Craddock, C., et al., Init. Repts. DSDP, 35: Washington (U.S. Govt. Printing Office), 489-496.

Gibbs, R. J., 1968. Clay mineral mounting techniques for X-ray diffraction analysis: a discussion. J. Sediment. Petrol., 38:242-244.

Griffin, J. J., Windom, H., and Goldberg, E. D., 1968. The distribution of clay minerals in the world ocean. Deep-Sea Res., 15: 433-459.

Hayes, J. B., 1973. Clay petrology of mudstones, Leg 18, Deep Sea Drilling Project. In Kulm, L. D., von Huene, R., et al., Init. Repts. DSDP, 18: Washington (U.S. Govt. Printing Office), 903-914.

Jackson, M. L., 1969. Soil chemical analysis-advanced course (2nd ed.): Madison, WI (University of Wisconsin).
Johnson, D. A., McDowell, S. E., Sullivan, L. G., and Biscaye, P. E., 1976. Abyssal hydrography, nephelometry, currents, and benthic boundary layer structure in the Vema Channel. J. Geophys. Res., 81:5771-5786.

Lawrence, J. R., $1979 .{ }^{18} \mathrm{O} /{ }^{16} \mathrm{O}$ of the silicate fraction of recent sediments used as a provenance indicator in the South Atlantic. Mar. Geol., 33:M1-M7.

LePichon, X., Ewing, M., and Truchan, M., 1971. Sediment transport and distribution in the Argentine Basin, 2. Antarctic bottom current passage into the Brazil Basin. Phys. Chem. Earth, 8: 31-48.

Lonardi, A. G., and Ewing, M., 1971. Sediment transport and distribution in the Argentine Basin, 4. Bathymetry of the continental margin. Argentine Basin and other related provinces. Canyons and sources of sediments. Phys. Chem. Earth, 8:79-121.

McCoy, F. W., and Zimmerman, H. B., 1977. A history of sediment lithofacies in the South Atlantic Ocean. In Supko, P. R., PerchNielsen, K., et al., Init. Repts. DSDP, 39: Washington (U.S. Govt. Printing Office), 1047-1079.

Melguen, M., Debrabant, P., Chamley, H., Maillot, H., Hoffert, M., and Courtois, C., 1978. Influence des courants profonds sur les faciès sédimentaires du Vema Channel (Atlantique sud) à la fin du Cénozoique. Bull. Soc. Geol. Fr., 20:121-136.

Rateev, M. A., Gorbunova, Z. N., Lisitzyn, A. P., and Nosov, G. L., 1969. The distribution of clay minerals in the oceans. Sedimentology, 13:21-43.

Reid, J. L., Nowlin, W. D., Jr., and Patzert, W. C., 1977. On the characteristics and circulation of the southwestern Atlantic Ocean. J. Phys. Oceanogr., 7:62-91.

Reynolds, R. C., Jr., and Hower, J., 1970. The nature of interlayering in mixed-layer illite-montmorillonites. Clays Clay Miner., 18: 25-36.

Robert, C., 1980. Climats et courants cénozoiques dans l'Atlantique Sud d'après l'etude des minéraux argileux (legs 3,39 et 40 DSDP). Oceanol. Acta, 3:369-376.

Robert, C., Herbin, J.-P., Deroo, G., Giroud d'Argoud, G., and Chamley, H., 1979. L'Atlantique Sud au Crétacé d'après l'étude des mineraux agrileux et de la matière organique (legs 39 et 40 DSDP). Oceanol. Acta, 2:209-218.

Supko, P. R., Perch-Nielsen, K., et al., 1977. Init. Repts. DSDP, 39: Washington (U.S. Govt. Printing Office).

Zimmerman, H. B., 1977. Clay mineral stratigraphy and distribution in the South Atlantic Ocean. In Supko, P. R., Perch-Nielsen, K., et al., Init. Repts. DSDP, 39: Washington (U.S. Govt. Printing Office), 395-405.

1982a. Fine-grained sediment distribution in the late Pleistocene/Holocene North Atlantic. Bull. Inst. Géol. Bassin Aquitaine, 31:337-357.

$1982 \mathrm{~b}$. Lithologic stratigraphy and clay mineralogy of the western Caribbean and eastern equatorial Pacific, Leg 68, Deep Sea Drilling Project. In Prell, W. L., Gardner, J. V., et al., Init. Repts. DSDP, 68: Washington (U.S. Govt. Printing Office), 383-395.

Date of Initial Receipt: March 9, 1982 